\title{
Proceedings
}

\section{Recycling-oriented design of the Al-Zn-Mg-Ca alloys ${ }^{\dagger}$}

\author{
Pavel Shurkin ${ }^{1, *}$, Nikolay Belov ${ }^{1}$, Torgom Akopyan ${ }^{1}$ and Zhanna Karpova ${ }^{1,2}$ \\ 1 Department of Metal Forming, National University of Science and Technology MISiS, 119049, Moscow, \\ Russia; pa.shurkin@gmail.com (P.S.); nikolay-belov@yandex.ru (N.B.); nemiroffandtor@yandex.ru (T.A.); \\ zkarpova2012@yandex.ru (Z.K.) \\ 2 Keldysh Research Center, 119049, Moscow, Russia \\ * Correspondence: pa.shurkin@gmail.com; Tel.: +79265851990 \\ + Presented at the 1st International Electronic Conference on Metallurgy and Metals, 22 February - 7 March \\ 2021; Available online: https://iec2m.sciforum.net/
}

Citation: Shurkin, P.; Belov, N.; Akopyan, T.; Karpova, Z. Recyclingoriented design of the Al-Zn-Mg-Ca alloys. 2021, 3, x.

https://doi.org/10.3390/xxxxx

Published: 22 February 2021

Publisher's Note: MDPI stays neutral with regard to jurisdictional claims in published maps and institutional affiliations.

Copyright: $\odot 2021$ by the authors. Submitted for possible open access publication under the terms and conditions of the Creative Commons Attribution (CC BY) license (http://creativecommons.org/licenses/by/4.0/).

\begin{abstract}
The approaches to the design of the recycling-tolerant $\mathrm{Al}-\mathrm{Zn}-\mathrm{Mg}$ alloys are formulated to be achieving via combined $\mathrm{Ca}, \mathrm{Fe}, \mathrm{Si}$, appropriate solidification condition and heat treatment. CalPhaD calculation and experimental study were employed for analysis of the Al-8\%Zn-3\%Mg alloy doped with $1-2 \% \mathrm{Ca}, \quad 0.5 \% \mathrm{Fe}$ and $0.5 \% \mathrm{Si}$. The Al-8\%Zn-3\%Mg- $1 \% \mathrm{Ca}-0.5 \% \mathrm{Fe}-0.5 \% \mathrm{Si}$ (AlZ$\mathrm{nMg} 1 \mathrm{CaFeSi}$ ) alloy was preliminarily found to be promising since it shows high equilibrium solidus, as-cast structure included curved phases ( $\mathrm{Al}), \mathrm{Al}_{3} \mathrm{Fe}, \mathrm{Al}_{2} \mathrm{CaSi}_{2}, \mathrm{Al}_{10} \mathrm{CaFe}_{2}$ and $(\mathrm{Al}, \mathrm{Zn})_{4} \mathrm{Ca}$ favouring the further spheroidization response during a two-step annealing $450{ }^{\circ} \mathrm{C}, 3 \mathrm{~h}+520{ }^{\circ} \mathrm{C}, 3 \mathrm{~h}$. Besides, the alloy shows the excellent age-hardening response $(195 \mathrm{HV}, \mathrm{T} 6)$ which does not yield the values of the base alloy and outperforms the values of the other experimental counterparts. Regarding feasibilities, the $80 \%$ reduction hot rolling was successfully conducted as well as a brief comparison to commercial 6063 impurities-tolerant alloys. As we showed qualitatively similar structural patterns and Fe and Si alloying opportunities, the AlZnMg1CaFeSi alloy may serve as a sustainable basis for further developing of the high-strength aluminum alloys tailored for manufacturing from scrap materials.
\end{abstract}

Keywords: Al-Zn-Mg-Ca alloys, iron, silicon, recycling, phase composition, microstructure

\section{Introduction}

The role of recycling in metallurgical engineering has always been essential and prevalent, having a critical impact not only on the global economy and energy consumption but also on ecological environment and human life. This is due to opportunities for reducing primary metals manufacturing that is commonly accompanied by hazardous dross and greenhouse gases emissions [1]. When considering aluminum and its alloys, their recycling is recognized to be the mature engine of recycling economics that is constantly developing under new technological approaches toward shredding, sorting, and castshop manufacturing $[2,3]$. However, though recycling has made an advance, the consumption of primary aluminum is kept at a high level (70\% primary, $30 \%$ recycled) that is mostly promoted by demand of premium wrought alloys, intolerant to impurities [1, 4 , 5]. Specifically, the strongest $7 \mathrm{xxx}(\mathrm{Al}-\mathrm{Zn}-\mathrm{Mg})$ alloys show a marked loss of ductility when Fe and Si impurities are present due to formation of harmful intermetallics ( $\beta$ type phases) $\mathrm{Al}_{3} \mathrm{Fe}, \mathrm{Al}_{5} \mathrm{FeSi}$ and $\mathrm{Al}_{7} \mathrm{Cu}_{2} \mathrm{Fe}$ which appear as faceted platelets up to several millimetres [6-8]. We find it drastic but expedient to develop new aluminum alloys which may be tolerant of the foregoing impurities.

Current research on the development of secondary aluminum alloys often bypasses $7 x x x$ family alloys and thus, most of the new compositions are not able to resemble in high strength. Some part of material scientists make the point on recycling of chips from the same family via powder metallurgy, also may include work on additions of reinforcement 
particles [9] and severe plastic deformation [10], but there is no sense in terms of impurities and sustainability for industrial scaling. Meanwhile, the Fe and Si determine the performance of the alloy not only in mechanical properties but also in corrosion resistance and physical properties like density [8, 11-13].

The available machine learning equipment and thermodynamic databases are already used for designing lightweight steels, sustainable materials for additive manufacturing and high-entropy materials. The approach used for years is a phase diagrams calculation (CalPhaD) providing projections on how the alloy would solidify or melt. In this sense, it seems to be possible to design a universal high-strength aluminum alloy using low-concentrations multiple elements aluminum corners constructed using both available data on multicomponent diffusion capacity and intermetallics range and an experimental approach in micro- and near-atomic scale. In favour to this approach, there are many works were performed on calculating of $\mathrm{Al}-\mathrm{Zn}-\mathrm{Mg}-\mathrm{Ni}-\mathrm{Fe}$ system, promoting of the new alloys with a justified Ni/Fe ratio of 1.1 for providing formation of 5 vol.\% of fine $\mathrm{Al}$. $\mathrm{FeNi}$ phase [14-16]. However, the Nickel is not allowed in recycling-oriented plants as it is a very expensive material. Calcium seems to be far more preferential since it is the third most abundant metal in the earth's crust Recently, several works on Al-Ca-Fe-Si alloys showed that calcium may bind the impurities into finely shaped ternary phases $\mathrm{Al}_{10} \mathrm{CaFe}_{2}$ and $\mathrm{Al}_{2} \mathrm{CaSi}_{2}$ $[17,18]$. In our recent research on Al-Zn-Mg-Ca-Fe [19] and Al-Zn-Mg-Ca-Si [20] alloys we showed that the foregoing phases may appear as a very fine constituent. However, joint $\mathrm{Ca}, \mathrm{Fe}$ and $\mathrm{Si}$ alloying has not been considered yet.

Having said the foregoing statements, this study aims to describe the approaches do design the recycling-oriented $\mathrm{Al}-\mathrm{Zn}-\mathrm{Mg}-\mathrm{Ca}$ alloys and present the preliminary results on the microstructure, hardening and feasibilities of the Al-Zn-Mg-Ca-Fe-Si alloys. The results may bring huge progress into a currently static field on the recyclability of the highstrength aluminum alloys.

\section{Materials and Methods}

Six model compositions based on the Al-8\%Zn-3\%Mg matrix were chosen for investigation. For the sake of demonstration of the joint alloying effect, we studied the base matrix alloy, Ca-free alloy doped with $\mathrm{Fe}$ and $\mathrm{Si}$ and alloys doped with different $\mathrm{Ca}$. Their chemical compositions, according to spectral analysis, are given in Table 1.

Table 1. Chemical compositions of the model alloys as determined by spectral analysis.

\begin{tabular}{ccccccc}
\hline \multirow{2}{*}{ Alloy } & \multicolumn{7}{c}{ Nominal and actual concentrations (in brackets), wt. \% } \\
\cline { 2 - 7 } & Zn & Mg & Ca & Fe & Si & Al \\
\hline AlZnMg & $8(8.1)$ & $3(2.8)$ & 0 & 0 & 0 & Balance \\
\hline AlZnMgFeSi & $8(7.9)$ & $3(2.9)$ & 0 & $0.5(0.51)$ & $0.5(0.49)$ & Balance \\
\hline AlZnMg1Ca & $8(7.7)$ & $3(2.6)$ & $1(0.9)$ & 0 & 0 & Balance \\
\hline AlZnMg2Ca & $8(7.8)$ & $3(3.1)$ & $2(1.8)$ & 0 & 0 & Balance \\
\hline AlZnMg1CaFeSi & $8(8.0)$ & $3(2.8)$ & $1(0.9)$ & $0.5(0.55)$ & $0.5(0.51)$ & Balance \\
\hline AlZnMg2CaFeSi & $8(7.7)$ & $3(2.9)$ & $2(1.9)$ & $0.5(0.52)$ & $0.5(0.50)$ & Balance \\
\hline
\end{tabular}

The CALPHAD (CALculation PHAse Diagram) approach implemented into Thermo-Calc software (Version 3.1, TCA14 Al-based alloy database, Thermo-Calc Software $\mathrm{AB}, 81$ Stockholm, Sweden) [21] was employed for analysis of phase composition and solidification behaviour. Its performance was also used for substantiating of the alloying content and heat treatment route shown further in the Results section. 
The experimental alloys were prepared by melting route in an electric resistance furnace Nabertherm K 1/13 (Nabertherm GmbH, 71 Lilienthal, Germany) using a $500 \mathrm{~g}$ capacity graphite crucible. The melts were carried out in an air atmosphere without the addition of protective gas. High-purity $(99.99 \%)$ and commercially pure $(99.9 \%)$ aluminium were employed as starting materials for Fe- and Si-free alloys and other alloys respectively. Following to melting of aluminium bulk, master alloys $\mathrm{A} 115 \% \mathrm{Ca}, \mathrm{Al} 10 \% \mathrm{Fe}$ and $\mathrm{Al} 10 \% \mathrm{Si}$ were added with continuous manual stirring down to their dissolution. Then, pure $\mathrm{Zn}$ (99.99\%) and $\mathrm{Mg}(99.99 \%)$ were added, followed by homogenization for $15 \mathrm{~min}$ at $730-750{ }^{\circ} \mathrm{C}$, skimming and pouring into the steel mould $15 \times 60 \times 180 \mathrm{~mm}$. The cooling rate was approximately $40{ }^{\circ} \mathrm{C} / \mathrm{s}$ as it was estimated by single-thermocouple plugged to the AKTAKOM-2006 recording unit. The latter technique was also used for thermal analysis of the $\sim 50 \mathrm{~g}$ samples slowly cooled in a furnace atmosphere.

Heat treatment of the samples included two-step annealing $450{ }^{\circ} \mathrm{C}, 3 \mathrm{~h}+520^{\circ} \mathrm{C}$, 3h and quenching in water (hereinafter referred to as T4) that will be approved in the Results section. Ageing was performed as isochronal low-temperature exposure at 175 for $3 \mathrm{~h}$ that is corresponded to T6 condition $[19,20]$. The microstructure was examined in as-cast and T4 conditions by scanning electron microscopy (SEM, TESCAN VEGA3) with an electron microprobe analysis system (EMPA, Oxford Instruments) and Aztec software. The samples were prepared by polishing with diamond suspension and electrochemical etching $\left(6 \mathrm{C}_{2} \mathrm{H}_{5} \mathrm{OH}, 1\right.$ $\mathrm{HClO}_{4}, 1$ glycerin). To control the properties evolved, a Vickers' hardness test at a load of 10 $\mathrm{g}(0.1 \mathrm{~N})$ and $15 \mathrm{~s}$ dwell was used.

\section{Results}

\subsection{Principles of the alloy design}

Before started experimental investigation the approaches to design novel alloys will be briefly clarified. In general, the main principles were taken from $[8,14,16]$, which describe a highly consistent action toward increasing impurities by developing multiphase eutectic structures. In these works they propose searching for existing eutectic mixture included differentiated Fe-bearing phase $\mathrm{Al}_{8} \mathrm{Fe} 2 \mathrm{Si}, \mathrm{Al} 9 \mathrm{FeNi}$ and $\mathrm{Al}_{16} \mathrm{Fe}_{4} \mathrm{Be}_{3} \mathrm{Si}_{2}$ along with ( $\mathrm{Si}$ ) or $\mathrm{Mg}_{2} \mathrm{Si}$ available in particular alloys based on $\mathrm{Al}-\mathrm{Fe}-\mathrm{Mg}-\mathrm{Si}$, Al-Fe-Ni-Si and $\mathrm{Al}-\mathrm{Fe}-\mathrm{Be}-\mathrm{Mg}-$ $\mathrm{Si}$. Besides, there are some recent works on Al-Ca-Fe-Si alloys containing $(\mathrm{Al})+\mathrm{Al}_{4} \mathrm{Ca}+\mathrm{Al}_{10} \mathrm{CaFe}_{2}+\mathrm{Al}_{2} \mathrm{CaSi}_{2}$ eutectic mixture. Regarding essential formation of multiphase eutectic, it is stipulated by substantial differentiation of the structure due to increase in the net volume fraction of the eutectic phases, providing a similar effect as it is due to increase in cooling rate. Indeed, the latter must be also controlled as a part for tuning solidification behaviour that must provide appropriate structure compatible with further treatment. The next step after solidification is homogenization treatment for stress relief, dissolving of non-equilibrium phases and favourable shaping of the insoluble phases. The latter, for example, is widely used in 6xxx alloys for the $\beta$-Fe phase to $\alpha$-Fe phase transformation, but the efficiency is dependent on the initial phase morphology. Schematic structure evolution in two-phase and three-phase eutectic alloys is presented in Figure 1. 


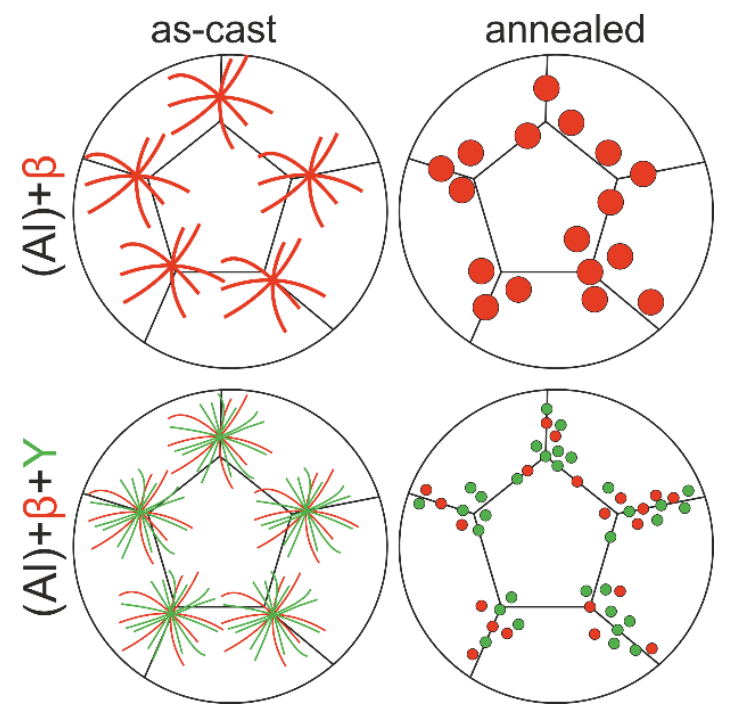

Figure 1. Schematic view of the two-phase and three-phase eutectics in as-cast and annealed conditions.

While the smooth surface of a needle- or plate-like $\mathrm{Al}_{3} \mathrm{Fe}$ and $\mathrm{Al}_{5} \mathrm{FeSi}$ phases is not stable against heating (even near solidus), the curved skeleton-like phases particularly $\mathrm{A}_{10} \mathrm{CaFe}_{2}$ and $\mathrm{Al}_{2} \mathrm{CaSi}_{2}$ may be fragmented or even spheroidized after exposure at $450-500$ ${ }^{\circ} \mathrm{C}$ due to far higher surface energy. Ultimately, the ways we followed for neutralization of the harmful recycling-originated $\mathrm{Fe}$ and $\mathrm{Si}$ impurities are as the following: (1) appropriate alloying and solidification conditions for achieving multiphase eutectic with curved intermetallics inside and (2) substantial heating near solidus for achieving globular and uniformly distributed intermetallics favouring the ductility at metal forming.

\subsection{Substantiation of the alloying content and heat treatment route}

When considering Al-Zn-Mg alloys, several works [14-16] used the foregoing principles for developing Fe-rich compositions via Ni alloying and providing $\mathrm{Al}$ (9FeNi phase formation. While the results are successful, the alloying approach may not be described as sustainable for practical application as nickel is an expensive element. Calcium, abundant in the earth crust, also very versatile in aluminides formation, specifically $\mathrm{Al}_{10} \mathrm{CaFe}_{2}$ and $\mathrm{Al}_{2} \mathrm{CaSi}$, favouring flexibility in recycling-tolerant $\mathrm{Al}-\mathrm{Zn}-\mathrm{Mg}-\mathrm{Ca}$ alloy design. Based on the available information [17-20], seven phases containing $\mathrm{Ca}$, Fe and $\mathrm{Si}\left((\mathrm{Al}, \mathrm{Zn}){ }_{4} \mathrm{Ca}\right.$, $\mathrm{Al}_{10} \mathrm{CaFe}_{2}, \mathrm{Al}_{2} \mathrm{CaSi}_{2}, \mathrm{Al}_{3} \mathrm{Fe}, \mathrm{Al}_{8} \mathrm{Fe}_{2} \mathrm{Si}, \mathrm{Al}_{5} \mathrm{FeSi}$ and $\mathrm{Mg}_{2} \mathrm{Si}$ ) may be in equilibrium with (Al) in the alloys of the considered system. The most probable distribution of the elements among these phases is given in Table 2. It can be seen that $\mathrm{Ca}, \mathrm{Fe}$ and $\mathrm{Si}$ additives do not form precipitates. Therefore, the hardening effect of the multicomponent alloy depends on the concentrations of $\mathrm{Zn}$ and $\mathrm{Mg}$ in (Al) before ageing (after quenching).

Table 2. Distribution of elements among phases in the Al-Zn-Mg-Ca-Fe-Si alloys.

\begin{tabular}{|c|c|c|c|c|c|c|}
\hline \multirow{2}{*}{ Phases } & \multicolumn{6}{|c|}{ Element } \\
\hline & Al & Zn & Mg & $\mathrm{Ca}$ & $\mathbf{F e}$ & Si \\
\hline \multicolumn{7}{|c|}{ Phases forming during solidification } \\
\hline$(\mathrm{Al}, \mathrm{Zn})_{4} \mathrm{Ca}$ & + & + & - & + & - & - \\
\hline $\mathrm{Al}_{10} \mathrm{CaFe}_{2}$ & + & - & - & + & + & - \\
\hline $\mathrm{Al}_{2} \mathrm{CaSi}_{2}$ & + & - & - & + & - & + \\
\hline $\mathrm{Al}_{3} \mathrm{Fe}$ & + & - & - & - & + & - \\
\hline$\alpha-\mathrm{Fe}\left(\mathrm{Al}_{8} \mathrm{Fe}_{2} \mathrm{Si}\right)$ & + & - & - & - & + & + \\
\hline
\end{tabular}




\begin{tabular}{|c|c|c|c|c|c|c|}
\hline$\beta$-Fe $\left(\mathrm{Al}_{5} \mathrm{FeSi}\right)$ & + & - & - & - & + & + \\
\hline $\mathrm{Mg}_{2} \mathrm{Si}$ & - & - & + & - & - & + \\
\hline $\mathrm{T}\left(\mathrm{Al}_{2} \mathrm{Mg}_{3} \mathrm{Zn}_{3}\right)$ & + & + & + & - & - & - \\
\hline M (MgZn2) & - & + & + & - & - & - \\
\hline \multicolumn{7}{|c|}{ Precipitates } \\
\hline $\mathrm{T}\left(\mathrm{Al}_{2} \mathrm{Mg}_{3} \mathrm{Zn}_{3}\right)$ & + & + & + & - & - & - \\
\hline M (MgZn $)$ & - & + & + & - & - & - \\
\hline
\end{tabular}

Unfortunately, the currently available CALPHAD databases do not count the existence of the $\mathrm{Al}_{10} \mathrm{CaFe}_{2}$ phase and the solubility of $\mathrm{Zn}$ in the $(\mathrm{Al}, \mathrm{Zn})_{4} \mathrm{Ca}$ phase. However, as our previous research on Al-Zn-Mg-Ca-Fe alloys [19] showed, the foregoing phases may appear as a result of non-equilibrium solidification induced by casting cooling rated, while slow-cooled samples included $\mathrm{Al}_{3} \mathrm{Fe}$ intermetallics. This case is quite similar to $\mathrm{Al}-\mathrm{Fe}-\mathrm{Mg}$ $\mathrm{Si}$ alloys, which may exhibit $\mathrm{Al}_{8} \mathrm{Fe}_{2} \mathrm{Si}$ phase instead of $\mathrm{Al}_{5} \mathrm{FeSi}$ phase upon accelerated cooling rate [8]. Having said that, the calculation data must be strongly supported by experimental evaluation. Preliminary, we provide several principles supported by our previous research on $\mathrm{Al}-\mathrm{Zn}-\mathrm{Mg}$ and Ca-rich aluminum alloys and CALPHAD calculation:

(1) $\mathrm{Zn}$ and $\mathrm{Mg}$ must provide as far as more sufficient hardening after solid solution treatment and ageing. With regards to further practical application, their amount (8 wt.\% and $3 \mathrm{wt} . \%$ ) was chosen out of concentrations in the established ultra-high-strength 7085 alloy and our previous studies. For example, the latter showed that excessive $\mathrm{Zn}(>10 \mathrm{wt} . \%)$ may bring lowering of equilibrium solidus and further grain-boundaries melting after homogenizing annealing at $500{ }^{\circ} \mathrm{C}$. Additionally, several works[22-24] revealed that an increase in $\mathrm{Zn}$ content over $9 \mathrm{wt} . \%$ is rather causing a decrease in ductility than an increase in strength. When considering $\mathrm{Mg}$, the content chosen is a maximum for commercial alloys [25]. An increase in $\mathrm{Mg}$ is practically used for increasing hot tearing resistance, while the toughness, essential for wrought alloys, may be tuned by lowering Mg:Zn ratio. Besides, as it is shown in Figure2a both $\mathrm{Zn}$ and $\mathrm{Mg}$ remarkably narrow the area of (Al) solidification. However, $\mathrm{Zn}$ acts in a slightly stronger manner and may bring some risks regarding unacceptable primary solidification of intermetallics.

(2) Ca provides a formation of the eutectic-origin phases, which may also include Fe and $\mathrm{Si}\left(\mathrm{Al}_{10} \mathrm{CaFe}_{2}, \mathrm{Al}_{2} \mathrm{CaSi}_{2}\right)$. An increase in the Ca content may bring far more benefits in improving density, corrosion resistance and casting properties. However, to the best of our knowledge, the Ca content must be controlled down to $2 \mathrm{wt} . \%$ due to limitation in industrial emission spectrometry for chemical analysis. Besides, the higher $\mathrm{Ca}$ the lower $\mathrm{Zn}$ in (Al) due to incrementing ( $\mathrm{Al}, \mathrm{Zn})_{4} \mathrm{Ca}$ phase, bringing the loss of strength. Further to the primary solidification, increase in Ca from $1 \mathrm{wt} . \%$ to $2 \mathrm{wt} \%$ shifts the equilibrium line $\mathrm{Al}_{3} \mathrm{Fe} /(\mathrm{Al})$ by $0.12 \mathrm{wt} . \%$. Hence, further $\mathrm{Ca}$ alloying may bring Fe-bearing primary phase at a given $\mathrm{Fe}$ and $\mathrm{Si}$ content.

(3) Fe and Si content each of $0.5 \mathrm{wt} . \%$ was chosen for the sake of sustainability providing opportunities to use commercially pure primary aluminium $(\mathrm{Fe}+\mathrm{Si}<0.5 \mathrm{wt} . \%)$, packing or electrical scrap of grades like 1100 and $8176(\mathrm{Fe}+\mathrm{Si}<1 \mathrm{wt} . \%)$. Indeed, these elements aggravate the performance of the alloy mainly due to possible formation of adverse $\mathrm{Al}_{3} \mathrm{Fe}$ and $\mathrm{Mg}_{2} \mathrm{Si}$ phases. According to preliminary calculation, even if the formation of the $\mathrm{Al}_{8} \mathrm{Fe}_{2} \mathrm{Si}$ may be achieved by an increase in Si content, it also would lead to excessive $\mathrm{Mg}_{2} \mathrm{Si}$ phase and lowering of effective $\mathrm{Mg}$ in (Al). In this respect, based on our previous studies we advocate our speculation on beneficial Ca effect in favouring of the microstructure due to the formation of ternary phases.

According to the polythermal section displayed in Figure $2 b$, the multicomponent Al-Zn-Mg-Ca-Fe-Si alloys undergo complicated phase transformations during equilibrium solidification included mainly eutectic-based precipitations from the liquid and further solid-state transformations included the formation of $\mathrm{T}, \mathrm{M}$ phases and $\mathrm{Mg}_{2} \mathrm{Si}$ phases. 


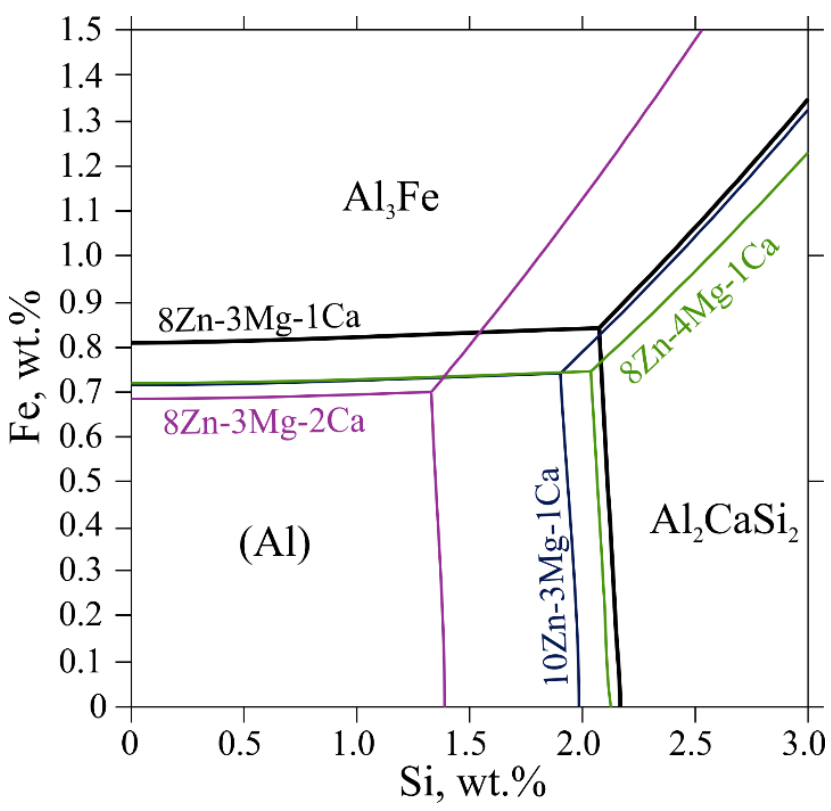

a

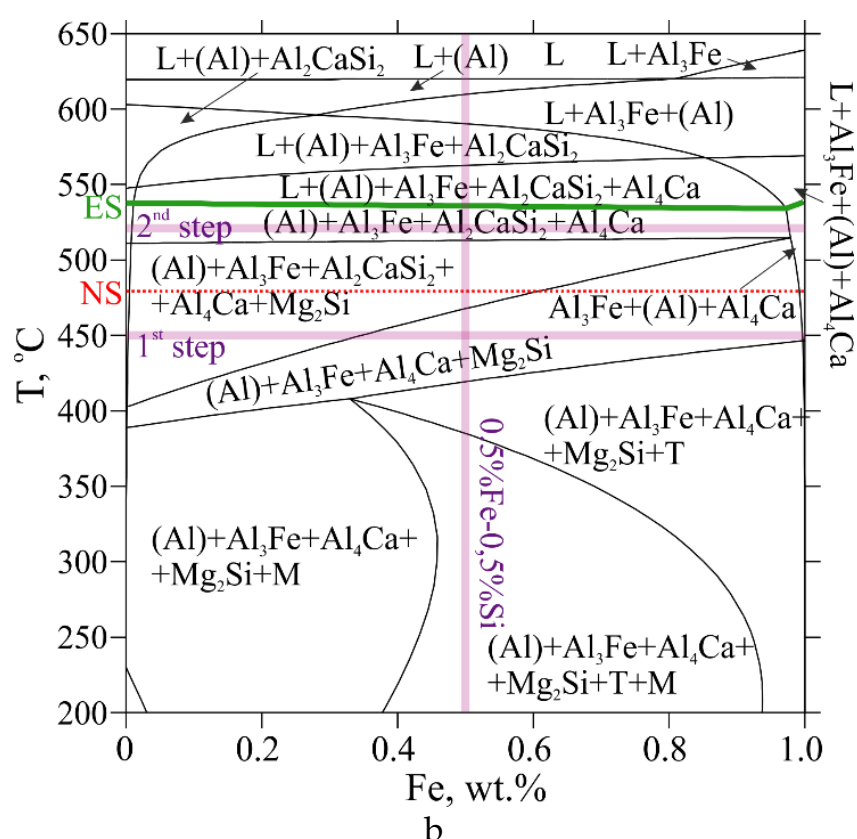

b

Figure 2. Figure 2. CALPHAD calculation results: a - liquidus projections of the Al-Zn-Mg-Ca-Fe-Si system at $8-10 \% \mathrm{Zn}, 3-4 \% \mathrm{Mg}$, $1-2 \% \mathrm{Ca} ; \mathrm{b}$ - polythermal section of the .Al-Zn-Mg-Ca-Fe-Si system at $8 \% \mathrm{Zn}, 3 \% \mathrm{Mg}, 1 \% \mathrm{Ca}$ and $1 \%(\mathrm{Fe}+\mathrm{Si})$.

By varying Fe:Si ratio it is possible to extend the cooling ranges for $\mathrm{Al}_{3} \mathrm{Fe}$ (or preferably $\mathrm{Al}_{10} \mathrm{CaFe}_{2}$ ) phase or $\mathrm{Al}_{2} \mathrm{CaSi}_{2}$ phase formation. Besides, this ratio influences on the $\mathrm{Mg}_{2} \mathrm{Si}$ solid-state transformation in the five-phase field ( $\left.\mathrm{Al}\right)+\mathrm{Al}_{3} \mathrm{Fe}+\mathrm{Al}_{2} \mathrm{CaSi}_{2}+\mathrm{Al}_{4} \mathrm{Ca}+\mathrm{Mg}_{2} \mathrm{Si}$. However, the latter is not expected as it would require the decay of the $\mathrm{Al}_{2} \mathrm{CaSi} 2$ phase, impossible due to low diffusion of Ca. Moreover, the formation of the $\mathrm{Mg}_{2} \mathrm{Si}$ in $\mathrm{Al}-\mathrm{Mg}$-Ca$\mathrm{Si}$ alloys proceeds via peritectic reaction $\mathrm{L}+\mathrm{Al}_{2} \mathrm{CaSi}_{2} \rightarrow(\mathrm{Al})+\mathrm{Al}_{4} \mathrm{Ca}+\mathrm{Mg}_{2} \mathrm{Si}$ [17], that might be suppressed in actual solidification conditions. As we chose equal concentrations $0.5 \% \mathrm{Fe}$ and $0.5 \% \mathrm{Si}$, the cooling range equality $\left(\sim 40{ }^{\circ} \mathrm{C}\right)$ between $\mathrm{Al}_{3} \mathrm{Fe}\left(\mathrm{Al}_{10} \mathrm{CaFe}_{2}\right)$ and $\mathrm{Al}_{2} \mathrm{CaSi}_{2}$ precipitations is expected. Indeed, it is preferable to obtain cast samples completely solidified at $\sim 540{ }^{\circ} \mathrm{C}$ (equilibrium solidus, the green line in Figure $2 \mathrm{~b}$ ) according to the equilibrium path in $(\mathrm{Al})+\mathrm{Al}_{3} \mathrm{Fe}\left(\mathrm{Al}_{10} \mathrm{CaFe}_{2}\right)+\mathrm{Al}_{2} \mathrm{CaSi}_{2}+\mathrm{Al}_{4} \mathrm{Ca}\left((\mathrm{Al}, \mathrm{Zn})_{4} \mathrm{Ca}\right)$ phase field. In that sense, the alloy would perform excellent casting properties and may be compatible with hightemperature homogenization for shape tuning of the intermetallics. However, under nonequilibrium (actual) solidification conditions, the alloy remains liquid until the precipitation of $\mathrm{T}$ and $\mathrm{M}$ phases at $\sim 480{ }^{\circ} \mathrm{C}$ (non-equilibrium solidus, the red dotted line in Figure $2 \mathrm{~b})$. It was calculated by Scheil-Gulliver simulation that confirmed that the solidification range increases from $\sim 80{ }^{\circ} \mathrm{C}$ to $\sim 140{ }^{\circ} \mathrm{C}$ due to formation of the non-equilibrium eutectic. This path is a key technological factor in 7xxx alloys determining their service temperatures and limited casting properties. It should be mentioned that the latter may be improved by the addition of eutectic-forming elements like Ca due to crack-healing factor and reduction in effective solidification range as it is shown in [26].

Summing up the calculation results, in terms of alloys design, we must choose the alloying content that provides a sufficiently high solidus temperature, which is achieved only in equilibrium conditions. This factor forces us to use a two-step annealing mode. According to the results of the thermal analysis, the actual temperatures are consistent with the calculated ones (Table 3). It follows the rules as the increase in alloying content leads to a decrease in liquidus and formations of the curvatures related to phase precipitations. It can be noticed, that $\mathrm{AlZnMg} 2 \mathrm{CaFeSi}$ does not show the formation of the nonequilibrium eutectic, that is probably due to excessive Ca content and extended dissolving $\mathrm{Zn}$ in the ( $\mathrm{Al}, \mathrm{Zn})_{4} \mathrm{Ca}$ phase, unfavourable to further solid solution and age-hardening. Nevertheless, the results allow us to profoundly substantiate the chosen heat treatment 
route included two-step annealing $450{ }^{\circ} \mathrm{C}, 3 \mathrm{~h}+520^{\circ} \mathrm{C}$, 3h, also approved to be efficient in our previous studies. The first step aims to dissolve non-equilibrium $\mathrm{Zn}$ - and $\mathrm{Mg}$-bearing non-equilibrium eutectic (mainly, $\mathrm{T}$ and $\mathrm{M}$ phase mixture) and falls into $(\mathrm{Al})+\mathrm{Al}_{3} \mathrm{Fe}\left(\mathrm{Al}_{10} \mathrm{CaFe} 2\right)+\mathrm{Mg}_{2} \mathrm{Si}+\mathrm{Al}_{4} \mathrm{Ca}\left((\mathrm{Al}, \mathrm{Zn})_{4} \mathrm{Ca}\right)$ field in the polythermal section. The second step ensures the absence of the $\mathrm{Mg}_{2} \mathrm{Si}$, since it falls into $(\mathrm{Al})+\mathrm{Al}_{3} \mathrm{Fe}\left(\mathrm{Al}_{10} \mathrm{CaFe}\right)_{2}+\mathrm{Al}_{2} \mathrm{CaSi}_{2}+\mathrm{Al}_{4} \mathrm{Ca}\left((\mathrm{Al}, \mathrm{Zn})_{4} \mathrm{Ca}\right)$ phase field, and it might be effective in shape tuning of the insoluble intermetallics with $\mathrm{Ca}$, Fe and $\mathrm{Si}$ up to their spheroidization.

Table 3. Transformation temperatures in the model alloys as determined by calculation and direct thermal analysis.

\begin{tabular}{|c|c|c|c|c|c|c|c|c|}
\hline \multirow{2}{*}{ Alloy } & \multicolumn{8}{|c|}{ Phase transformation temperatures (calculation/experimental), ${ }^{\circ} \mathrm{C}^{1}$} \\
\hline & $\mathrm{L}^{1}$ & $\mathrm{Al}_{3} \mathrm{Fe}^{2}$ & $\mathrm{Mg}_{2} \mathrm{Si}$ & $\mathrm{Al}_{4} \mathrm{Ca}^{3}$ & $\mathrm{Al}_{2} \mathrm{CaSi}_{2}$ & $\mathrm{~T}$ & $\mathrm{NS}^{2}$ & $\mathrm{ES}^{2}$ \\
\hline $\mathrm{AlZnMg}$ & $632 / 628$ & & & & & $483 / 474$ & 482 & 559 \\
\hline $\mathrm{AlZnMgFeSi}$ & $627 / 623$ & $615 / 613$ & $564 / 561$ & & & $480 / 471$ & 474 & 560 \\
\hline $\mathrm{AlZnMg1Ca}$ & $626 / 623$ & & & $566 / 589$ & & $482 / 470$ & 478 & 545 \\
\hline $\mathrm{AlZnMg} 2 \mathrm{Ca}$ & $619 / 617$ & & & $578 / 594$ & & $482 / 468$ & 477 & 540 \\
\hline AlZnMg1CaFeSi & $620 / 616$ & 610/- & $526 /-$ & $559 /-$ & $589 / 585$ & $482 / 468$ & 477 & 538 \\
\hline AlZnMg2CaFeSi & $613 / 610$ & 605/- & $526 /-$ & 574/- & $591 / 598$ & 481/- & 478 & 535 \\
\hline
\end{tabular}

${ }^{1} \mathrm{~L}$ - liquidus; NS - non-equilibrium solidus; ES - equilibrium solidus

${ }^{2} \mathrm{Al}_{10} \mathrm{CaFe}_{2}$ as it is expected in actual solidification conditions

${ }^{3}(\mathrm{Al}, \mathrm{Zn}){ }_{4} \mathrm{Ca}$ as it is expected in actual solidification conditions

\subsection{Samples in as-cast and heat-treated conditions}

As the AlZnMg, AlZnMg1Ca and AlZnMg2Ca were substantially considered in [] and showed an intrinsic as-cast microstructures consistent with $(\mathrm{Al})+\mathrm{T}$ and $(\mathrm{Al})+\mathrm{T}+(\mathrm{Al}$, $\mathrm{Zn})_{4} \mathrm{Ca}$ phase compositions, these alloys will be considered as counterparts in hardness measurement to those containing Fe and Si. The microstructure of the as-cast AlZnMgFeSi alloy (Figure 3a) exhibits clearly defined $\mathrm{T}$ phase as bright veins intrinsic to 7xxx alloys, $\mathrm{Mg}_{2} \mathrm{Si}$ phase as dark faceted plates and $\alpha$-Fe phase as chinese-script constituents. Indeed, the presence of the latter is not consistent with the calculation probably due to nonequilibrium solidification conditions but indeed it is much more favourable than $\mathrm{Al}_{3} \mathrm{Fe}$ phase. However, the morphology of the $\alpha$-Fe phase in some places is quite needled and its prevalent size is more than $20 \mu \mathrm{m}$, that is believed to be incompatible with further annealing-induced fragmentation. Generally, if both $\mathrm{Mg}_{2} \mathrm{Si}$ and $\alpha$-Fe do not show spheroidization after heat treatment, they will certainly aggravate ductility as well as strength due to lowering the saturation of $(\mathrm{Al})$. On the contrary, the addition of $1 \%$ and $2 \%$ Ca promotes a sufficient change in the microstructure that is displayed in figures $3 \mathrm{~b}$ and $3 \mathrm{c}$ accorded to as-cast $\mathrm{AlZnMg1CaFeSi}$ and $\mathrm{AlZnMg} 2 \mathrm{CaFeSi}$ alloys. It is striking that there is no $\mathrm{Mg}_{2} \mathrm{Si}$ appeared and thus most $\mathrm{Si}$ is likely bonded into the Ca-containing phase. As it is shown in [20], the $\mathrm{Al}_{2} \mathrm{CaSi}_{2}$ may have coarse faceted morphology specifically in Al$\mathrm{Zn}-\mathrm{Mg}$ alloys containing $2 \% \mathrm{Ca}$. The presented results also show a significant coarsening of the structure in the AlZnMg2CaFeSi alloy compared to the AlZnMg1CaFeSi alloy. Hence, the latter may have the best response to annealing tuning, since it presents the curved intermetallics with the least linear size. It is prominent that the most coarse area presented as magnified in Figure 4a included no Fe but $\mathrm{Ca}, \mathrm{Zn}$ and Si corresponded to $(\mathrm{Al})+\mathrm{T}+(\mathrm{Al}, \mathrm{Zn})_{4} \mathrm{Ca}+\mathrm{Al}_{2} \mathrm{CaSi}_{2}$ eutectic mixture. When considering the phase composition of the AlZnMg1CaFeSi alloy that is supported by elemental maps, $\mathrm{Zn}$ is distributed among $(\mathrm{Al}), \mathrm{T}$ and $(\mathrm{Al}, \mathrm{Zn})_{4} \mathrm{Ca}$ as a dominating element along with $\mathrm{Ca}$. The latter turned to be successful to bind all the silicon resulted in absence of the $\mathrm{Mg}_{2} \mathrm{Si}$ phase, while for iron its effect is ambiguous because there is clearly-defined $\mathrm{Al}_{3} \mathrm{Fe}$ phase (specified by a triangle in Figure $3 \mathrm{~b}$ and Figure $4 \mathrm{~b}$ ) and also Ca-rich particles probably to be $\mathrm{Al}_{10} \mathrm{CaFe}_{2}$ phase 
(specified by a circle in Figure $3 \mathrm{~b}$ and Figure $4 \mathrm{~b}$ ). Summing up the analysis of the as-cast structures, the most promising alloy $\mathrm{AlZnMg} 1 \mathrm{CaFeSi}$ is not perfect as aligned in the section on the design principles, but outperforms the Ca-free and 2\%-Ca bearing counterparts in the size of intermetallics and their morphology.
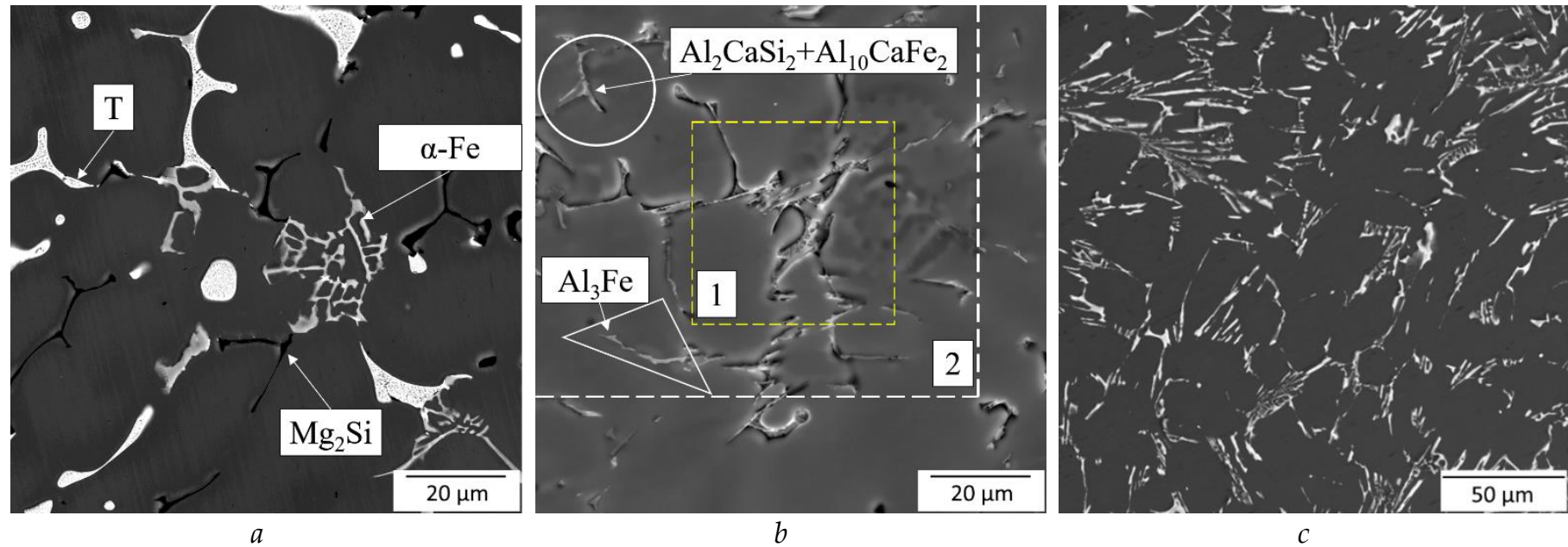

Figure 3. The microstructure of the experimental alloys in as-cast condition: a - AlZnMgFeSi alloy; b - AlZnMg1CaFeSi alloy ( 1 - area for magnification, see in Figure 4a, 2 - area for EMPA analysis, see Figure 4 b); c - AlZnMg2CaFeSi.

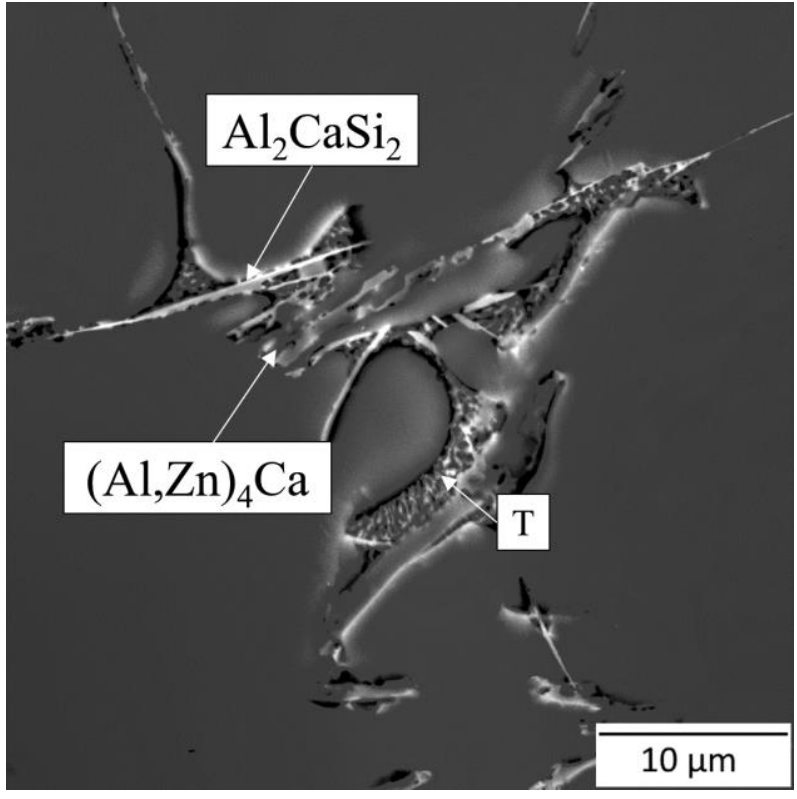

$a$
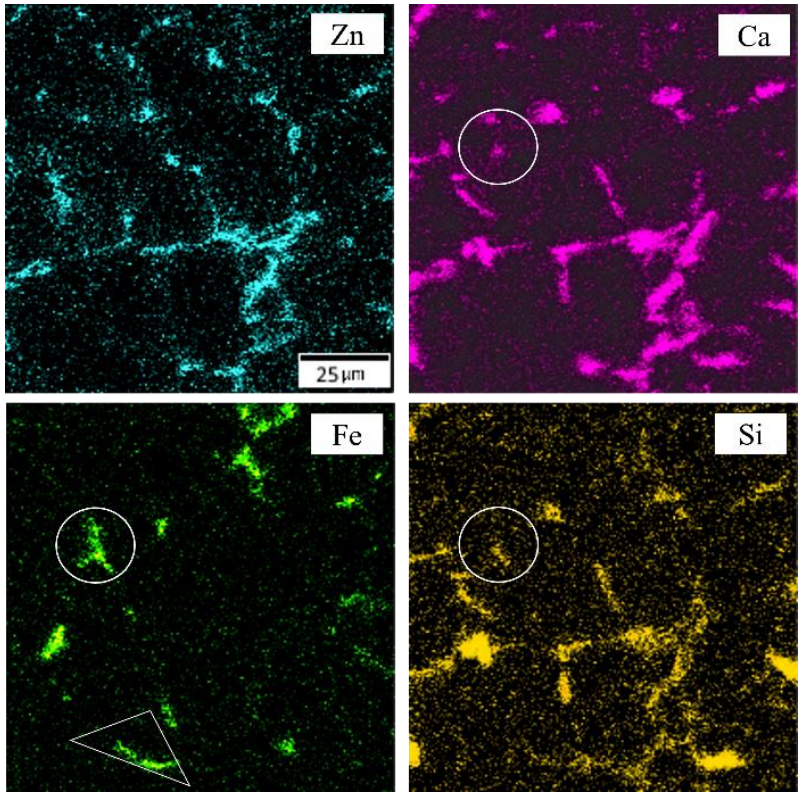

Figure 4. Specific analysis of the as-cast $\mathrm{AlZnMg} 1 \mathrm{CaFeSi}$ alloy microstructure: a - magnified section showing the Ca-containing eutectic mixture; $\mathrm{b}$ - EMPA elemental mapping on $\mathrm{Zn}, \mathrm{Ca}, \mathrm{Fe}, \mathrm{Si}$.

Two-step annealing and further quenching of experimental alloys resulted in a complete dissolution of the $\mathrm{T}$ phase in $(\mathrm{Al})$. As a result, the base AlZn1Mg alloy becomes a single-phase one, and in other alloys, there is a certain amount of particles containing $\mathrm{Ca}$, $\mathrm{Fe}$ and $\mathrm{Si}$, since these elements are approximately insoluble in $(\mathrm{Al})$. The effect of heat treatment on the morphology of these particles is different. When it comes to Fe and Sifree alloys, they exhibit a favourably spheroidized structure, that may be observed in [20]. The structure of the $\mathrm{AlZnMgFeSi}$ includes the $\mathrm{Mg}_{2} \mathrm{Si}$ phase of a globular morphology and the chinese-script $\alpha$-Fe phase has not sufficiently modified (Figure 5a). The microstructure 
of the $\mathrm{AlZnMg} 1 \mathrm{CaFeSi}$ alloy is more favourable since the particles are distributed more uniformly (Figure $5 b$ ). The total number of eutectic particles in this alloy decreases in comparison with the cast state (compare Figure $3 b$ and Figure $5 b$ ), primarily due to the dissolution of the $\mathrm{T}$ phase. At the same time, the $(\mathrm{Al}, \mathrm{Zn})_{4} \mathrm{Ca}$ phase retains in the structure, but acquire a globular morphology. The Fe- and Si-rich phases show faceted shape but their size is comparable to that of $(\mathrm{Al}, \mathrm{Zn})_{4} \mathrm{Ca}$ particles, that is most likely due to fragmentation upon exposure at $520^{\circ} \mathrm{C}$.

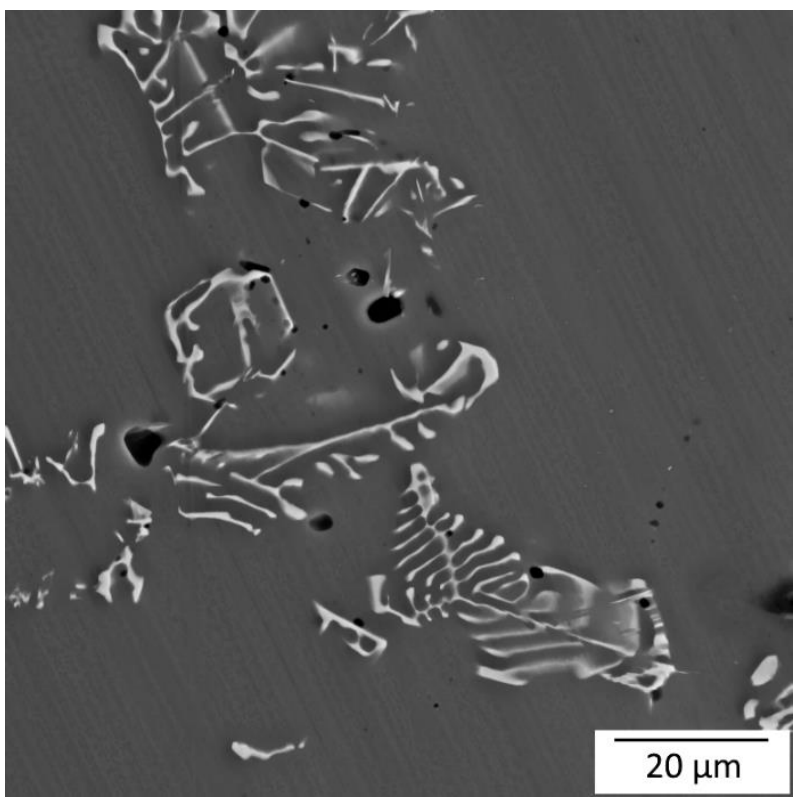

$a$

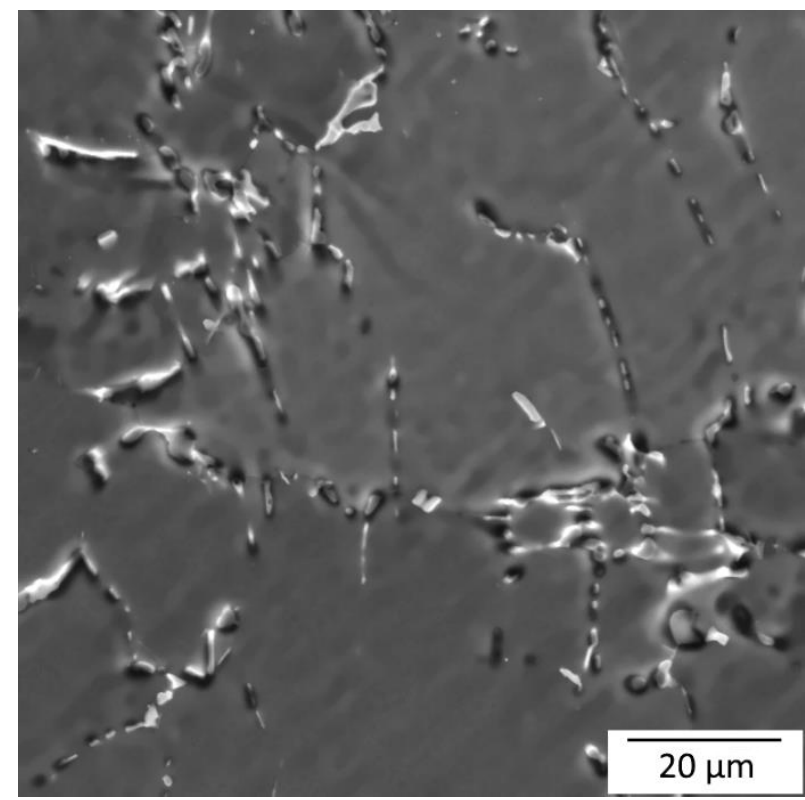

$b$

Figure 5. The microstructure of the experimental alloys in T4 condition: a - AlZnMgFeSi alloy; b - AlZnMg1CaFeSi alloy.

The analysis of hardening showed that the $(\mathrm{Al}, \mathrm{Zn})_{4} \mathrm{Ca}$ phase brings a decrease in effective $\mathrm{Zn}$ content in (Al) and weakening of ageing response in $\mathrm{AlZnMg1Ca}$, $\mathrm{AlZnMg} 2 \mathrm{Ca}$ and AlZnMg2CaFeSi alloys (170-180 HV in T6) in comparison to the base AlZnMg alloy ( $200 \mathrm{HV}$ in T6). A quite similar result was demonstrated on AlZnMgFeSi (185 HV in T6) due to formation of insoluble $\mathrm{Mg}_{2} \mathrm{Si}$ phase along with lowering of the effective $\mathrm{Mg}$ solubility. On the contrary, joint alloying with $1 \% \mathrm{Ca}$, Fe, and $\mathrm{Si}$ provides appropriate strengthening (195 HV in T6) probably due to decrease in the amount of (Al, $\mathrm{Zn})_{4} \mathrm{Ca}$ and binding of $\mathrm{Ca}$ with $\mathrm{Fe}$ and Si-bearing phases.

\subsection{Deformation and recycling feasibility}

As known, the main aggravating effect of Fe and $\mathrm{Si}$ in 7xxx alloys is a marked reduction in ductility. For ensuring appropriate plasticity upon rolling, we conducted hot rolling in a solute condition provided by temperature $400^{\circ} \mathrm{C}$. It is shown in Figure 6, that the base alloy and both alloys $\mathrm{AlZnMgFeSi}$ and $\mathrm{AlZnMg1CaFeSi}$ showed quite a similar performance under hot rolling reduction of $\sim 80 \%$. It may be speculated, that the base alloy was rolled in a high ductility solute condition, the AlZnMgFeSi alloy is successful due to effective breaking of the Chinese-script particles and the AlZnMg1CaFeSi does not yield due to very fine microstructure provided uniform load distribution along with the bulk. In contrary, the $\mathrm{AlZnMg} 2 \mathrm{CaFeSi}$ alloy has cracked at a reduction of $60 \%$ that is most probably due to its coarse structure. 


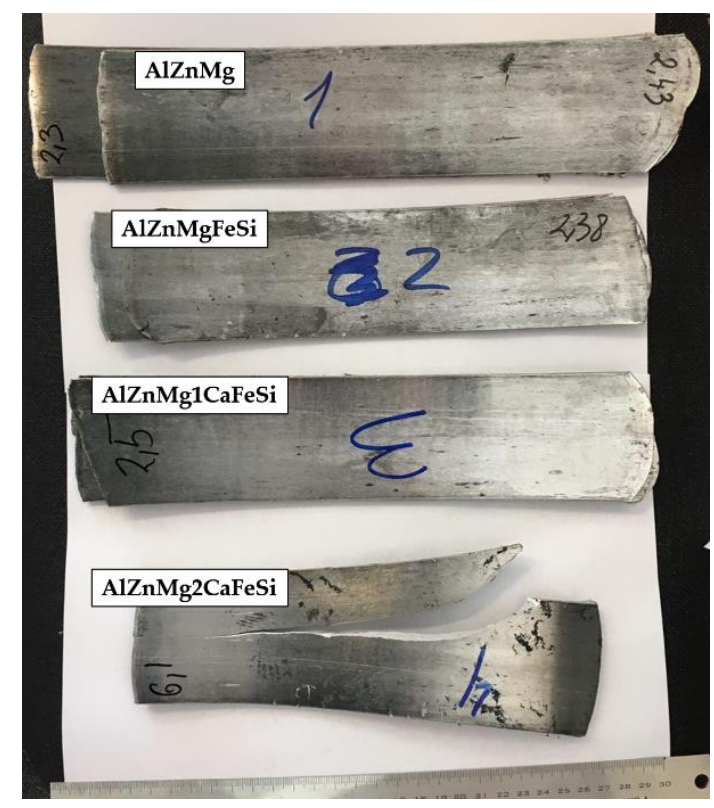

Figure 6. Experimental sheet products.

When it comes to recycling feasibility, it is mostly dependent on the shape of Fe- and Si-bearing intermetallics obtained in the homogenized ingot and final wrought product. The structure of the ingot must favour the efficient rolling or extrusion with a high reduction ratio and surface quality in the product. Ultimately, the comparison between AlZ$\mathrm{nMgFeSi}$ and $\mathrm{AlZnMg} 1 \mathrm{CaFeSi}$ reveals the efficiency of joint $\mathrm{Ca}$, Fe and Si alloying in obtaining fine microstructure before metal forming comparable to homogenized 6xxx billets manufactured by DC casting. Actually, the latter may bring higher cooling rates and uniformity in the structure due to controlled solidification conditions. As for 6xxx alloys, they are recognized as the main pillar among recyclable aluminum alloys. We analyzed one of the most representative 6063 alloy (Al-0.45Mg-0.43Si-0.37Fe-0.1Cu-0.07Mn-0.02Ti) as supplied by JSC Aluminium Alloys Plant (Podolsk, Russia) and formulated from secondary stock, like wheels, taint tabor scrap and drinking cans. Besides, conductor 1xxx alloys were used for dilution and achieving the nominal grade. Firstly, the alloy's composition is very suitable to be the basis for the AlZnMg1CaFeSi model alloy. Despite that 6063 type grades have a very low strength performance (UTS 200 MPa), they are highly widespread in the fields, like construction and automotive ones, their stream is huge and so appealing to be recycled into high-strength aluminium alloys. When comparing the as-cast structures of the AlZnMg1CaFeSi alloy (Figure3b) and 6063 alloy (Figure 7a), we can notice that the latter contains far fewer intermetallics but they are mostly needle-shaped related to $\beta$-Fe. However, after homogenizing annealing at $560^{\circ} \mathrm{C}$ for $9 \mathrm{~h}$, there is an immense change due to the spheroidization happened (Figure $7 \mathrm{~b}$ ). The structure qualitatively resembles the pattern presented in Figure $5 \mathrm{~b}$ on the AlZnMg1CaFeSi alloy in $\mathrm{T} 4$ condition and is most intrinsic to currently recycling-tolerant wrought aluminum alloys. Summing up, it may be preliminary concluded that the new $\mathrm{Al}-\mathrm{Zn}-\mathrm{Mg}-\mathrm{Ca}-\mathrm{Fe}-\mathrm{Si}$ alloys show a promise to be efficiently formulated from Fe- and Si-rich aluminum scrap included 6xxx series, conductors and other low-alloyed Al-Fe-Si grades. 


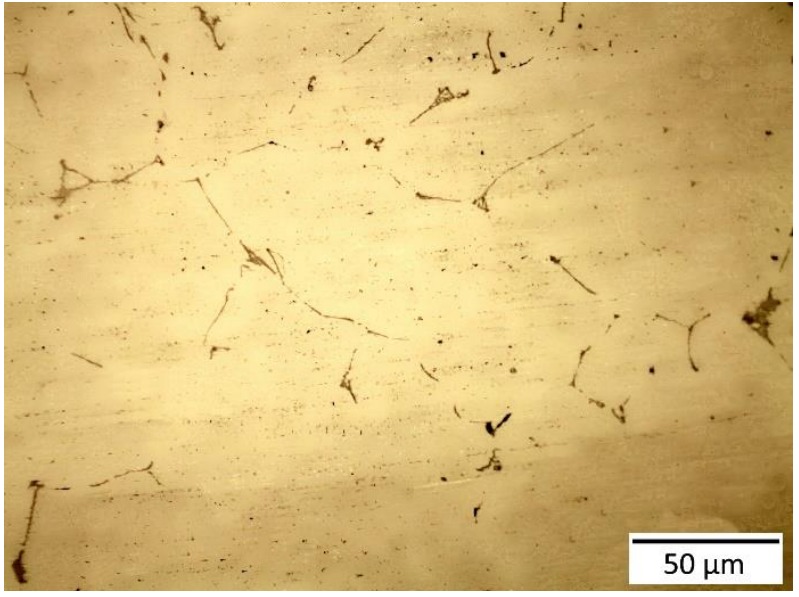

a

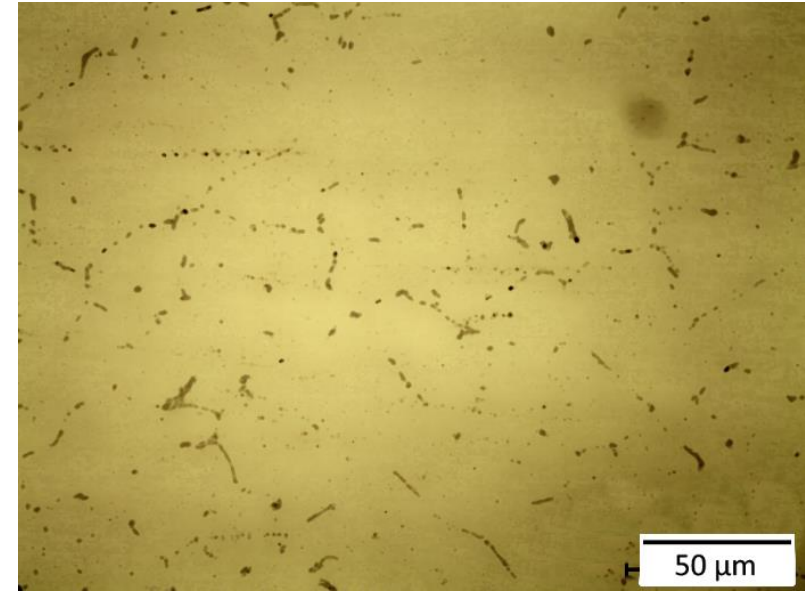

$\mathrm{b}$

Figure 7. The microstructure of the 6063 alloy as supplied by JSC Aluminium Alloys Plant (Podolsk, Russia): a - ascast condition; $\mathrm{b}$ - annealed condition.

\section{Conclusions}

In this study, we described the approach to design the recycling-tolerant $\mathrm{Al}-\mathrm{Zn}-\mathrm{Mg}$-Ca aluminum alloys, carried out an experimental study on the Al-Zn-Mg-Ca-Fe-Si alloys and chose the most promising one that was briefly compared with commercial counterparts. The main conclusions are as following:

1. The recycling-tolerant Al-Zn-Mg-Ca aluminum alloys may be formulated via appropriate alloying and solidification conditions provided as-cast structure included multiphase eutectic with differentiated insoluble intermetallics which must contain impurities of recycling origin, primarily, Fe and Si. Accordingly, the solidification path and solidus temperature must provide the opportunity for high-temperature heat-treating aimed to tune the shape of the eutectic phase favouring the performance.

2. The phase composition and solidification path of the Al-Zn-Mg-Ca-Fe-Si alloys showed the presence of multiphase eutectic $(\mathrm{Al})+\mathrm{Al}_{3} \mathrm{Fe}+\mathrm{Al}_{2} \mathrm{CaSi}_{2}+\mathrm{Al}_{4} \mathrm{Ca}$ under equilibrium solidus of $540{ }^{\circ} \mathrm{C}$. However, the first annealing step at $450{ }^{\circ} \mathrm{C}$ is required for the dissolving of the non-equilibrium eutectic solidified at $\sim 480^{\circ} \mathrm{C}$.

3. In comparison to $\mathrm{AlZnMgFeSi}$ and $\mathrm{AlZnMg} 2 \mathrm{CaFeSi}$, the AlZnMg1CaFeSi exhibited sufficiently fine as-cast structure included differentiated constituents of equilibrium origin $\mathrm{Al}_{3} \mathrm{Fe}, \mathrm{Al}_{10} \mathrm{CaFe}_{2}$, $\mathrm{Al}_{2} \mathrm{CaSi}_{2}$ and $(\mathrm{Al} . \mathrm{Zn})_{4} \mathrm{Ca}$. After two-step annealing and quenching they were mostly spheroidized along with non-equilibrium $\mathrm{T}$ phase was dissolved in $(\mathrm{Al})$.

4. A synergetic $\mathrm{Ca}, \mathrm{Fe}, \mathrm{Si}$ effect on the hardening was described. While the Al-Zn-Mg-Ca alloys lose their performance due to $\mathrm{Zn}$ dissolution in ( $\mathrm{Al}, \mathrm{Zn})_{4} \mathrm{Ca}$ phase the joint $\mathrm{Ca}, \mathrm{Fe}, \mathrm{Si}$ alloying promotes the formation of additional Ca-bearing phases and an increase in effective solute $\mathrm{Zn}$ in (Al). The AlZnMg1CaFeSi in T6 condition possess a similar hardness value as the base $\mathrm{AlZnMg}$ alloy (195 HV vs $200 \mathrm{HV})$.

5. The composition related to the AlZnMg1CaFeSi alloy may serve as a sufficient basis for the design of the new high-strength recycling-tolerant wrought aluminium alloys since it shows good microstructure similar to that of 6xxx alloys, excellent hardening response, appropriate processability at metal forming, and may be formulated from Fe- and Si-rich aluminum scrap.

Author Contributions: Conceptualization, P.S.; methodology, N.B. and T.A.; software, Z.K.; validation, N.B.; formal analysis, P.S.; investigation, P.S. and Z.K.; resources, N.B.; data curation, T.A.; writing-original draft preparation, P.S.; writing - review and editing, N.B.; visualization, P.S.; supervision, N.B.; project administration, T.A.; funding acquisition, T.A. All authors have read and agreed to the published version of the manuscript.

Funding: This research was funded by the Russian Science Foundation, Project № 20-79-10373. 
Institutional Review Board Statement: Not applicable.

Informed Consent Statement: Not applicable.

Conflicts of Interest: The authors declare no conflict of interest. The funders had no role in the design of the study; in the collection, analyses, or interpretation of data; in the writing of the manuscript, or in the decision to publish the results.

\section{References}

1. Raabe, D.; Tasan, C.C.; Olivetti E.A. Strategies for improving the sustainability of structural metals. Nature 2019, 575, 64-74 https://doi.org/10.1038/s41586-019-1702-5

2. Trowell, K.A.; Goroshin, S.; Frost, D.L.; Bergthorson, J.M. Aluminum and its role as a recyclable, sustainable carrier of renewable energy. Applied Energy 2020, 275, 115112 https://doi.org/10.1016/j.apenergy.2020.115112

3. Haraldsson, J.; Johansson, M.T. Review of measures for improved energy efficiency in production-related processes in the aluminium industry - From electrolysis to recycling. Renewable and Sustainable Energy Reviews 2018, 93, 525-548 https://doi.org/10.1016/j.rser.2018.05.043

4. Wallace, G. Production of secondary aluminium. In Fundamentals of Aluminium Metallurgy Production, Processing and Applications, 1st ed.; Lumley, R.; Woodhead Publishing Ltd.: Cambridge, UK, 2011, pp. 70-82 https://doi.org/10.1533/9780857090256.1.70

5. Das, S.K.; Green, J.A.S.; Kaufman, J.G.The development of recycle-friendly automotive aluminum alloys. JOM 2007, 59, 47-51 https://doi.org/10.1007/s11837-007-0140-2

6. Cinkilic, E.; Ridgeway, C.D.; Yan, X.; Luo, A.A. A formation map of iron-containing intermetallic phases in recycled cast aluminium alloys. Metall. Mater. Trans. A 2019, 50A, 5945-5956 https://doi.org/10.1007/s11661-019-05469-6

7. Park, J.O.; Paik, C.H.; Huang, Y.H.; Alkire, R.C. Influence of Fe-Rich intermetallic inclusions on pit initiation on aluminum alloys in aerated $\mathrm{NaCl}$. Journal of The Electrochemical Society 1999, 146, 517-523 https://doi.org/10.1149/1.1391637

8. Belov, N.A.; Aksenov, A.A.; Eskin, D.G. Iron in aluminum alloys: impurity and alloying element. Taylor \& Francis: London, UK, 2002, 360 p.

9. Enginsoy, H.M.; Bayraktar, E.; Katundi, D.; Gatamorta, F.; Miskioglu, I. Comprehensive analysis and manufacture of recycled aluminium-based hybrid metal matrix composites through the combined method; sintering and sintering + forging. Composites Part B: Engineering 2020, 194, 108040

10. Hyodo, A.; Bolfarini, C.; Ishikawa, T.T. Chemistry and tensile properties of a recycled AA7050 via spray forming and ECAP/E. Materials Research 2012, 15, 5, 739-748 https://doi.org/10.1590/S1516-14392012005000097.

11. She, H.; Chu, W.; Shu, D.; Wang, J.; Sun, B. Effects of silicon content on microstructure and stress corrosion cracking resistance of 7050 aluminum alloy. Transactions of Nonferrous Metals Society of China 2014, 24, 7, 2307-2313 https://doi.org/10.1016/S1003-6326(14)63349-5

12. Kazeem, A.; Badarulzaman, N.A.; Ali, W.F.F.W. Relating fractographic analysis to yield strength of novel X7475 (Al-Zn-Mg$\mathrm{Cu}$ ) alloys produced by recycling aluminium beverage cans. Materials Letters 2020, 262, 127067 https://doi.org/10.1016/j.matlet.2019.127067

13. Kazeem, A.; Badarulzaman, N.A.; Ali, W.F.F.W. Optimization of wear and hardness of Al-Zn-Mg-Cu alloy fabricated from recycled beverage can using response surface methodology. SN Appl. Sci. 2020, 2, 1210 https://doi.org/10.1007/s42452-0202836-7

14. Belov. N.A. Sparingly alloyed high-strength aluminum alloys: Principles of optimization of phase composition. Metal Science and Heat Treatment 2012, 53, 9 - 10, 420-427 https://doi.org/10.1007/s11041-012-9409-3

15. Akopyan, T.K.; Belov, N.A. Calculation-experimental study of the phase composition of Al-Zn-Mg-(Cu)-Ni-Fe aluminum alloys. Russian Metallurgy (Metally) 2013, 7, 545-552 https://doi.org/10.1134/S0036029513070021 
16. Akopyan, T.K.; Belov, N.A. Approaches to the design of the new high-strength casting aluminum alloys of 7xxx series with high iron content. Non-ferrous Metals 2016, 1, 20-27 https://doi.org/10.17580/nfm.2016.01.04

17. Belov, N.A.; Naumova, E.A.; Akopyan, T.K.; Doroshenko, V.V. Phase diagram of the Al-Ca-Fe-Si system and its application for the design of aluminum matrix composites. JOM 2018, 70, 2710-2715. https://doi.org/10.1007/s11837-018-2948-3

18. Belov, N.; Akopyan, T.; Korotkova, N.; Murashkin, M.; Timofeev, V.; Fortuna, A. Structure and Properties of Ca and Zr Containing Heat ResistantWire Aluminum Alloy Manufactured by Electromagnetic Casting. Metals 2021, $11,236$. https://doi.org/10.3390/ met11020236

19. Shurkin, P.K.; Dolbachev, A.P.; Naumova, E.A.; Doroshenko, V.V. Effect of iron on the structure, hardening and physical properties of the alloys of the $\mathrm{Al}-\mathrm{Zn}$ - Mg - Ca system. Tsvetnye Metally 2018, 5, 69-77 https://doi.org/10.17580/tsm.2018.05.10

20. Shurkin, P.K.; Belov, N.A.; Musin, A.F.; Samoshina M.E. Effect of calcium and silicon on the character of solidification and strengthening of the Al-8\% Zn-3\% Mg Alloy. Phys. Metals Metallogr. 2020, 121, 135-142. https://doi.org/10.1134/S0031918X20020155

21. Thermo-Calc Software-Computational Materials Engineering. Available online: http://www.thermocalc.com (accessed on 1 February 2021).

22. Shu, W.X.; Hou, L.G.; Zhang, C.; Zhang, F.; Liu, J.C.; Liu, J.T.; Zhuang, L.Z.; Zhang, J.S. Tailored Mg and Cu contents affecting the microstructures and mechanical properties of high-strength Al-Zn-Mg-Cu alloys. Mater. Sci. Eng. A 2016, 657, $269-283$. https://doi.org/10.1016/j.msea.2016.01.039

23. Chen, Z.; Mo, Y.; Nie Z. Effect of Zn content on the microstructure and properties of super-high-strength Al-Zn-Mg-Cu alloys. Metall. Mater. Trans. 2013, 44A, 3910-3920. https://doi.org/10.1007/s11661-013-1731-x

24. Shin, J.; Kim, T.; Kim, D.E.; Kim, D.; Kim, K. Castability and mechanical properties of new 7xxx aluminum alloys for automotive chassis/body applications. JALCOM 2017, 698, 577-590 http://dx.doi.org/10.1016/j.jallcom.2016.12.269

25. The Aluminium Association, International Alloy Designations and Chemical Composition Limits for Wrought Aluminium and Wrought Aluminium Alloys. The Aluminium Association. Available online: https://www.aluminum.org/sites/default/files/Teal\%20Sheets.pdf (accessed on 1 February 2021).

26. Shurkin, P.K.; Belov, N.A.; Musin, A.F.; Aksenov, A.A. Novel high-strength casting Al-Zn-Mg-Ca-Fe aluminum alloy without heat treatment. Russ. J. Non-ferrous Metals 2020, 61, 179-187. https://doi.org/10.3103/S1067821220020121 